\title{
Using Drama in Museum Education
}

\section{Enas Ibrahim Karim*}

enaskarim80@gmail.com

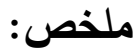

يتناول هذا البحث أهمية ودور استخدام الدراما (مثل التاريخ القصصي

والمسرح المتحفي) في المتاحف المصرية إذا تم تبنيها كوسيلة لتحسين تفسير معروضات المتحف وكأداة تعليمية في المتحف.

يمكن أن يكون هذا البحث نموذجًا أوليًا لبرامج التاريخ القصصي في المتاحف المصرية لاستخدامه كأداة فعالة لتفير المعروضات المتحفية بطريقة أفضل. إلى جانب ذلك، يسعى إلى إثبات أن برامج التاريخ القصصي يمكن أن تكون مفيدة وفعالة إذا تم تتفيذها في المتاحف المصرية وفقًا لخطة

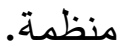
في الآونة الأخيرة، استخدمت المتاحف طرقًا متعددة لتفسير المعارض مثل المرشد الصوتي، الديوراما، اللوحات، إلخ. بالإضافة إلى ذلك، هناك طريقة مهمة جدًا وفعالة لتحسين تفسير المتحف الذي يُعرف بالتاريخ القصصي والمسرح المتحفي الذي يستخدم كوسيلة لتحسين أداء العرض المتحفي، يعتبر أداة تعليمية في المتحف، ووسيلة للترفيه عن الزوار • الكلمات المفتاحية: التاريخ القصصي - المسرح المتحفي - الدراما - التربية المتحفية - تفسير العرض المتحفي

* Studying PhD of Heritage and Museum Studies Faculty of Tourism and Hotel Management, Helwan University. 


\section{$\underline{\text { Abstract }}$}

This research tackles the importance and effective role of using drama (such as living history and museum theater) in Egyptian museums if it is adopted as a mean to improve the museum's exhibit interpretation and as a tool of education in the museum.

This research can be a prototype for the living history programs in the Egyptian Museums to be used as an effective tool for interpreting museum exhibit in a better way. Besides, it seeks to prove that the living history programs can be useful and effective if it is implemented in the Egyptian Museums according to an organized plan.

Recently, the museums have been using multiple ways to interpret the exhibitions such as audio guides, dioramas, panels, etc. In addition to that, there is a very important and effective way to improve the museum's interpretation that is known as living history and museum theater, which is used as a mean to improve the museum's interpretations, considered as an educational tool in the museum, and a method to entertain visitors.

Keywords: Living History - Museum Theater - Drama Museum Education - Museum Interpretation. 


\section{Introduction}

Today, education is the base of any museum's mission. This education should be the result of excellent interpretation of the museum exhibit and thus the museum should concentrate first on the method of interpretation and how to introduce an interpretive program of enjoyable and meaningful nature, with behavioral and emotional objectives, interesting and memorable, that could be accessible for all visitors. ${ }^{1}$

The museum must interpret the collection in an enjoyable and understandable way, developing interpretive programs to make objects culturally and physically accessible for the widest range of visitors. The methods of interpretation should vary between audio guide, video shows, dioramas and models of objects, three dimensions show using augmented reality, explanation by person to person or person to group, brochures, books, then captioned pictures, outdoor panels, activity programmers and the living history show which can be a re performance for historical events or museum theater.

Using drama in museum education such as ( living historymuseum theater-reenactment) which the research concentrates on is one of the efficient methods of museum interpretation as it aims to improve the knowledge, understanding and promotion of the history, as well as to educate people through accurate and comprehensive historical portrayals and reconstructions. 
The living history has become an influential educational mean used by interpreters, associations and schools to educate students and people in particular areas of history, such as clothing styles, pastimes and handicraft, or simply to convey a sense of the everyday life of a certain time period. This way the living history can play an important role in supporting the history lessons as another useful means of teaching, complementary to formal education and traditional methods, supporting and extending them. This is thanks to the immediacy and vividness of a threedimensional sensory experience. ${ }^{2}$

In addition, the living history also plays an enormous function in raising the awareness of people to the traditional museums by the diversity of their offerings and services for the visitors, promoting the cultural and heritage tourism. The living history represents an effective way to understand our heritage, to protect and preserve it for the future generations, as well as to enhance the tourist resources of the local communities in every aspect: landscape, nature, culture, arts and crafts. So, open-air and traditional museums, castles, parks and other heritage sites are turning more and more into living history services provide their visitors with an inspiring and educational experience through animated displays, interactive presentations and hands-on activities. ${ }^{3}$

The researcher discusses the previous studies of using drama in educational programs in the museums from a number of different perspectives. First, literature of living 
history theater. Then, literature of history of museum theater, Then, literature of education through museum theater.

The researcher made the direct observations during the field visits to examine the museum theater in Egypt and its impact on the visitors and how it can be effective and how it can be a useful tool to serve the community. The researcher made individual interviews of open - ended questions with the specialists in the Egyptian museums to get their opinions about the effect of the museum theater in Egypt and how it can a tool for museum education.

"Museum Theatre" is a term that has been used to refer both to the performance of theatre) in or by a museum and also to the use of any of a variety of theatrical techniques by museums.

Live Theatrical Program: A live interpretive presentation with skilled performers who engage museum visitors (including field trips and outreach) by portraying characters and conveying a story or dramatic narrative. Theatrical museum programs can take the form of a scripted play, dramatic demonstration, living history and first-person interpretation, puppetry, role play, music, movement, creative drama and simulation, gallery characters and enactors interacting with visitors, among others. $^{4}$ 


\section{History of the Museum Theater}

Museum Theater has been widely used as an educational tool in both museums and historical sites in the Unites States since a long time. The prototype in the use of the theater was at the Science Museum of Minnesota, which began using theatrical techniques and storytelling in 1971, whereas in historic sites, Colonial Williamsburg was the first attempt. In art museums, occasional attempts at storytelling and various theatrical endeavors took place over the last hundred years, while more recently, children's museums have provided participatory performances and often activities in which children become the performances of the drama. The distinguished examples of recent theater programs in the United States, are the Monterey Bay Aquarium, the Minnesota Historical Society and the Museum of Science. In particular the Minnesota History Center has a seasonal program of live performance within its exhibitions. The Center began using individual characters from Minnesota history who roam through the galleries and interact with visitors and subsequently expand to include more formal presentations of short plays. Through those plays, the Center is able to expose complicated issues such as immigration, race and socioeconomic. ${ }^{5}$ 


\section{Living History Theater}

Living History Theater is a sort of community theater, which develops plays, usually the play would deal with a historical theme of social or political topic, and is presented via various dramatic techniques (pantomime, movement, improvisation, song). The plays often have a cinematographic frame (short scene intersperse with song and dance). ${ }^{6}$

The process of the living history theater is often more important than its product, this is not to say that the actors in the play do not aim to make their performances as fine as possible, but they consider the ways of developing living history theater to be an end unto itself: to develop the artist within each individual, and to boost education about the participants themselves and their historical, social, and political contexts. Sharing these things with an audience is their essential target, and although the directors of the theatrical display do not intentionally involve their participants in personal or group therapy, they all agree that their process has, to different degrees, a therapeutic effect. ${ }^{7}$

Museum theater is widely defined as the use of theater as a tool of moderating knowledge and understanding in the context of museum education. The museum theater try to convey the broad fields of science, history and art. Museum theater employs the narrative structure and emotional engagement of drama to achieve educational aims.

The museum theater could take place in zoos, galleries, aquaria, art galleries and historic sites, presented by 
professional actors or volunteers. It could be a performance of short plays or monologues based on historical events or materials exhibited on-site, or an interactive event using performance specified to the curriculum needs of visiting school children, or directed to family groups and or the independent visitor. ${ }^{8}$

The performance had been used as an educational tool in museums and at heritage sites, had its roots in a number of broad traditions: the theater-based practice of participatory theater already referred to, and the museum-based practice of first or third person interpretation. First and third person interpretation is less overtly performance-based: it generally involves interpreters (with or without actor-training) in appropriate period costume interacting with visitors to interpret a heritage site or museum collection. ${ }^{9}$

The first-person interpreter acquires a specific role or character and talks to visitors as though from the period; the third-person interpreter remains herself in the present while talking about the past. While the character's biography and historical background will be carefully researched, there is no script and no fixed pattern for the interaction with visitors. That interaction will be responsive, conversational, enriched by anecdotal storytelling. ${ }^{10}$

\section{Education through Museum Theater}

There are two different categories of pedagogic theater: a theater created exclusively to transmit information (art, science and history) and another theater created for 
implanting morals, behaviors, and attitudes, but still maintaining its own "artistic expression". The museum theater falls into both categories, and that often it contains both elements. In the first category would fall the museum theater that has developed from science or historic craft demonstrations, with theatrical elements added to enhance the quality of the presentation. This category of museum theater will sometimes try to use theater elements such as lights, sound, and character in order to explain some scientific phenomena, such as explaining the components of a natural phenomenon or (in an art gallery) the steps of an artistic process. $^{11}$

In the second category, performances examine the social and ethical implications of a discipline, controversy, strife, and the nature of humanity. Theater such as this maintains its roots as pedagogy, while preserving and employing the full structure and potential power of theater. ${ }^{12}$

\section{The Museum Theater in Egypt}

The museum theater in Egypt was started a short time ago by the Ministry of Culture, as one of the most important preliminary experiences in the field of museums theatrical display, which was presented in the Museum of Mohammed Nagy in 2010, and started its first experience with presenting the play "Ana Karakter". That was the beginning of the idea of museum theater which should be applied and circulated in the other museums. Based on that, the management of cultural programs at the sector of fine arts in the ministry of culture is currently implementing an integrated program for 
the museum theater in four locations. The program was designed by the program director, Mahinaz Maher, and the workshops were organized for preparing the educators who will implement this program. ${ }^{13}$

The program includes:

- Organizing workshops to qualify and prepare a working team in each site to be capable of implementing the museum's theater.

- Establishment of workshops to coordinate the program of each site and that includes:

- Preparing activities and lectures in fine art.

- Preparation of activities and lectures in the elements of theatrical displays.

- Establishing special event for each site at the end of the program to:

$>$ View the results of art activities.

$>$ Hold a theatrical display composed of elements of the outcomes of theater workshops.

- Holding a competition between museum exhibitions to choose the best show that achieved the objectives of the theater museum ${ }^{14}$

The Ministry of Antiquities began in 2002 to implement the idea of the museum theater at the Greco-Roman museum, that did not follow a specific program and did not circulate to all museums, it was only applied in the Egyptian museum and was linked to the implementation of certain events or activities in it. For example, the first play displayed at the 
Egyptian Museum was on the occasion of the hundredth anniversary of its establishment. Then other plays were implemented and were often in collaboration with schools within the program of social communication of the educational section of the Egyptian Museum. ${ }^{15}$

The theatrical display was performed (The kings of Egypt and Iraq) in 2014 in cooperation with one of the secondary schools, students wrote the story and also performed the play. (The Egyptian Farmer) play was implemented in 2015 and also displayed by school students. These plays were displayed in the garden of the Egyptian Museum, associated with events or activities such as World Museums Day or World Heritage Day. ${ }^{16}$

Another theatrical display had been implemented at The Manial Palace Museum in 2016, the play was (Mohamed Ali the grandfather judges Mohamed Ali the grandson). ${ }^{17}$

The Blind school in the Egyptian Museum played a large role in the implementation of theatrical displays. For example the Blind school implemented the play (The Golden Snake) in 2008, directed by Adel Mustafa, one of the blinds and supervisor of the Blind school, the translation of the story by Dr. Wafaa Siddiq, the scenario by Tahany Nouh, the Director of the Blind School in the Egyptian Museum, clothes by Tahany Nouh and the performance by a group of the blind students from Shoubra School. Other plays such as "Honesty and Lies" performed in 2009, and (Zanan w Nadman) in 2015 and repeated again in 2016 and was exhibited at the Opera house and was presented again at 
the Egyptian Museum on the occasion of the Day of Archaeologists. ${ }^{18}$

\section{A Proposed Plan for the Museum Theater (for Nasser Museum)}

\section{Vision about Museum Theater Plan}

To make the visit to the museum more enjoyable, meaningful, interesting and memorable and to educate entertainment.

\section{Mission of the Museum Theater Plan}

- Developing a specific plan to be a reference for museums to use in the development of the museum theater program.

- Identifying the targeted audience of the museum theater and dealing with them in the museum theater program to know their motives for the visit, their desires and needs.

- Determination of the actors in the stage and their role in museum theater. 


\section{Targeted Audience}

- School trips: whose curriculum contains a subject about Gamal Abdel Nasser and his historical era.

- Teenagers: who have a strong motivation to know the history and achievements of one of the most important Arab leaders.

- Seniors: who lived in Nasser's time and had a desire to visit his museum.

- Nasser lovers: who are intrigued and eager to see the house of Nasser and his possessions.

- Tourists: who expect an interesting information.

- Researchers: who expect to get full information and a library in the museum.

- Local community: that expect to get engaged with the museum and the events held in it.

\section{Tools}

A place (the environment in which the theater event takes place) - stage and chairs - sound system - light system costumes.

\section{Team work}

- Curators: who prepare the scientific material for the theater display.

- Educators: who train the participants and volunteers taking part in the theater display.

- Director: who manages the theatrical display and supervise its implementation. 
- Script writer: who outlines the story of the theater display as well as training the participants and volunteers on how to write the story and the scenario of the theatrical display.

- Fashion designer: who designs the costumes of the historic era in association with the museum curators.

- Designer: who designs the theater in cooperation with volunteers and trains the volunteers on how design the theater.

\section{Workshops}

The preparation of workshops for all participants in the museum theater is conducted by theatrical work specialists in cooperation with the museum's curators and educators to train the volunteers and a group of community members in order to involve the community in the activities of the museum.

\section{Marketing}

It is possible to use the museum theater as a kind of publicity for the museum, thus the museum theater can be used to increase the number of visitors, but first the museum should develop a marketing using all available tools for marketing the theatrical display such as advertising in a publication or Facebook.

\section{Budget and funding}

The theater must have the necessary fund for the theatrical display to appear in a good form and in the absence of sufficient budget for the theatrical display, the museum 
should seek sponsors to fund the display and in return allowing the sponsors to advertise themselves.

\section{Evaluation}

The museum theater should be evaluated, the strengths and weakness points should be identified and the extent of the benefit of the theatrical display be determined by conducting interviews with the audience who attended the theatrical display, as well as with the participants and volunteers.

\section{Conclusion}

This research focuses on one of the activities of living history which is "The Museum Theater", because of its great importance and its great impact on the museum. The museum theater has a great role in interpreting the museum exhibit to the public in a simplified way and help to explain the museum exhibit it is also important mean of education in museums, that helps to increase the interaction and engagement between the community and the museum and can be used as a mean of marketing the museum and increasing the number of its visitors.

According to the literature review, the living history which the research concentrated on is one of the efficient methods of museum interpretation since the living history practices aims to improve the knowledge, understanding and promoting of history, as well as to educate people through accurate and comprehensive historical portrayals. 
In order to prove this, the researcher implemented a practical study and field observation, recording the history of the museum theater in Egypt and theatrical displays which were carried out in museums. In addition to conducting many personal interviews with the curators of museums educators, theater specialists and actors.

Many individual interviews have been done with different curators of the Egyptian museum. Nine out of ten of them confirmed the efficiency of the living history and their opinion was: The living history is an effective instrument in interpreting the museum exhibit by changing the mental image of the audience formed by the fixed collections exhibited in the museum.

Thus, it will convey to the audience the main idea of the exhibited collections which is reflecting the social, political and environmental life that surrounded the artifacts and how these artifacts were related to the surrounding society and influenced by it in contemporary life and its interpretation of reality and help predicting the future.

- They also said that it is one of the most interesting means of interpreting the museum exhibit and presenting the information in a fun setting which is the closest to the audience. And on the other hand, one curator of the Egyptian Textile Museum answered that the living history does not have any importance in the museum interpretation.

There are many individual interviews that have been done with different educators in museums and teachers in schools, six out of six of them confirmed the importance of the living 
history and especially the museum theater as a tool for informal education and their opinions were: The museum education aims to enhance the ability of visitors to understand the contents of the museum and to appreciate it by all means. Living history is one of the most important means through which we can convey and achieve the goals of museum education, as the museum theater depends on converting the museum collections into a theatrical script which focuses on the collections of the museum and relates to it. It is recommended to involve the public or individuals in the living history theater whether in the writing or the representation and directing of the play assisted by specialists in this field.

- Education specialists in schools regard that the role of theater is to strengthen the concept of belonging in the child, attaching the child to the heritage as the museum theater provides information in a simplified manner suitable for all age groups. In addition, the theater museum is one of the most interesting methods of museum education.

\section{Recommendation}

- There should be an annual calendar of the museum's theater in each museum.

- Incorporating the museum theater as one of the educational tools in the museums.

- Cooperation between museum curators, scriptwriters and actors prepare theatrical displays.

- The audience must be involved in the museum theater and historical events. 
- Training the students of the Cinema and Theater institute in partnership with museums and the Ministry of State for Antiquities and the Ministry of Culture, so that their projects are directed to serve the community outreaches of museums and activate and promote the tourism.

- Holding competitions between the different colleges and choosing the best offered project for a theatrical display in the museum.

- In the absence of a theater in the museum, a theatrical display could be organized in any archaeological area close to the museum for example in the case of The Egyptian Textile Museum the theater can be held in Al Moez Street.

- The museum's theaters should be presented not only in the museum, but also in public parks and squares as a kind of publicity for the museum.

- Use the written and existing plays which are taught in schools and universities and converting them to a theatrical display in the museum, such as the play "Cleopatra" for Shawqi and the play "Tiba's struggle" for Naguib Mahfouz which would create a link between the students and the museum.

- Each museum must have a theater team composed of museum curators and trained regularly and periodically.

- The theatrical display must be organized in a systematic and repetitive manner according to a schedule in which the theater activity is included.

Suggestions for museums where a museum theater could be held:

- Om Kalthoum Museum

- The Coptic Museum 
- The Museum of Islamic Art

- The Egyptian Air Force Museum

- Mahmoud Mokhtar Museum

- The Nubian Museum

- Helwan Corner Museum

- Sadat Museum

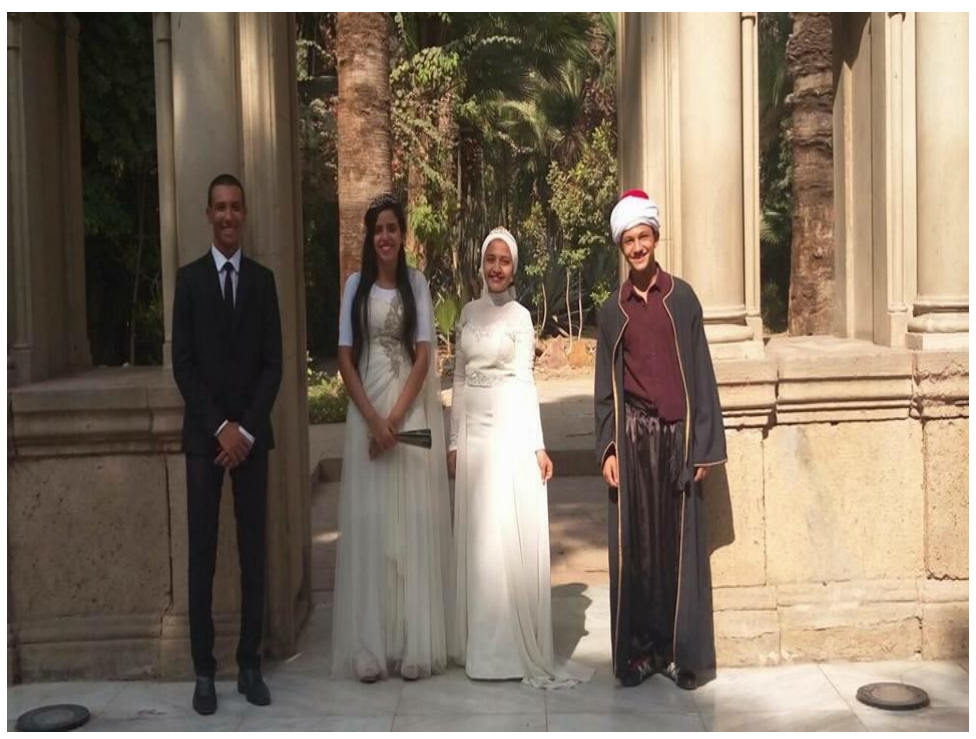

The theatrical display (Mohamed Ali to judge Mohamed Ali Manial Palace Museum Source@ Manial Palce Museum 


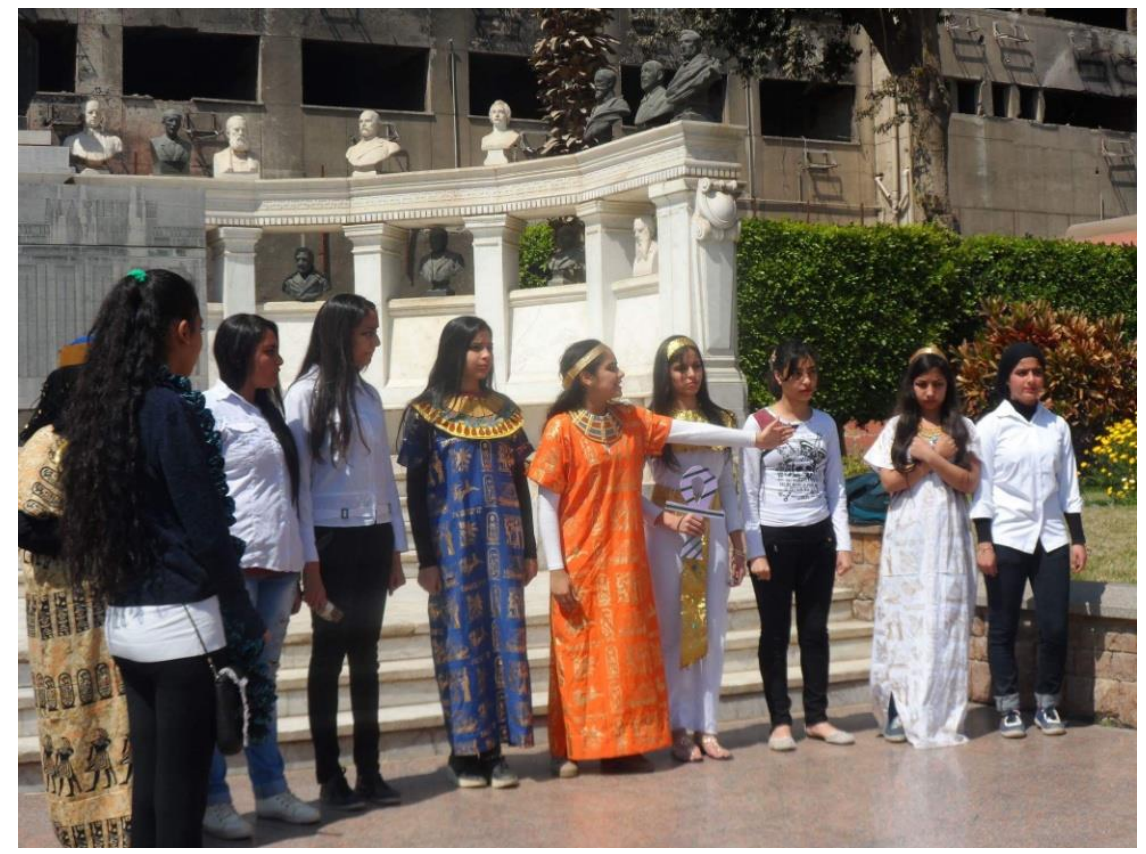

The theatrical display( The Kings of Egypt and Iraq)

The Egyptian Museum Source @ sayeda safwat

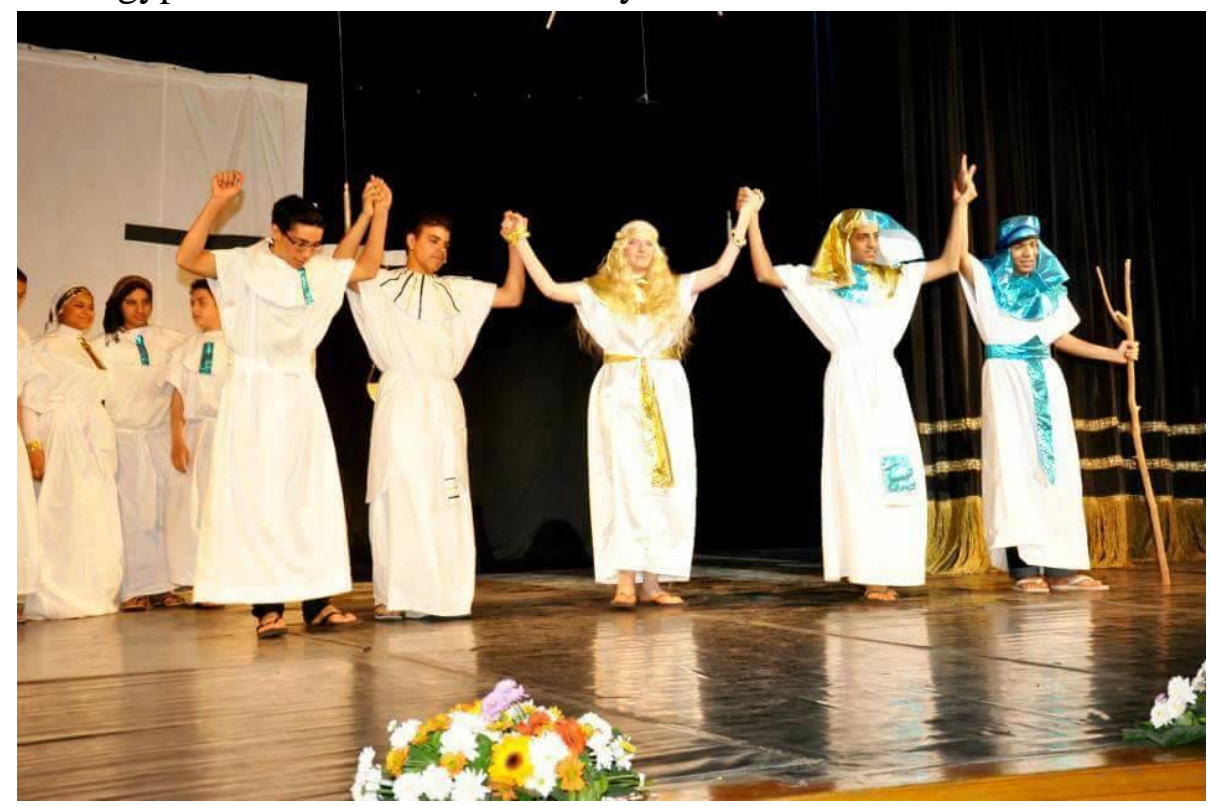

The theatrical display ( The golden snake )

The blind school in The Egyptian Museum Source@Tahany Nouh 


\section{Bibliography}

- Adel,Hadeer. Interview by Enas Karim, September7, 2017.

- Alsford, Stephen. \& Parry, David - Interpretive Theatre A Role in Museums?, Museum Management and Cimtorship (1991), 10, 823,p.1.

- Anderson, Jay. Living history: Simulating everyday life in living museums. American Quarterly, 34(3), 1982, pp.290-306.

- Bailey, Christine. "From Narrative to Theatre: Living History Theatre" (Doctoral Dissertation, City University of New York, 1985).

- Barbacci, Silvana. Science and Theatre: A Multifaceted Relationship Between Pedagogical Purpose and Artistic Expression, 8th International Conference on Public Communication of Science and Technology (PCST), Barcelona, Spain, 3-6 June 2004, p.2.

- EL seddik,Wafaa. Our Heritage Between Past, Present and Future - Museum Education Why?,Supreme Council of Antiquities, Cairo,2003. 
- Hughes, Catherine \& Jackson, Anthony.\& Kidd, Jenny. The Role of Theater in Museums and Historic Sites: Visitors, Audiences, and Learners. International handbook of research in arts education, 2007, pp.679-699.

- International Museum Theatre Alliance, Recommended Best Practices for Museum Theatre,Adopted by the membership at Atlanta Conference August, 2012

- Kamal,Rasha. Interview by Enas Karim, September 25, 2017.

- Nouh,Tahany,Interview by Enas Karim, September,26, 2017.

- Safwat,Sayada. Interview by Enas Karim, September, 26, 2017.

- Siebenaler ,Katherine. Hands-on History: Living History Museums and Children's History Education, 2012. 


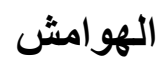

1. Wafaa EL seddik, Our Heritage Between Past, Present and Future-MuseumEducation Why ?,Supreme Council of Antiquities, Cairo,2003,P25.

2- Jay Anderson, Living history: Simulating everyday life in living museums. American Quarterly, 34(3),1982, pp.290-306.

3- Katherine Siebenaler, Hands-on History: Living History Museums and Children's History Education,2012,p3.

4- International museum theatre alliance, Recommended Best Practices for Museum Theatre Adopted by the membership at Atlanta Conference August, 2012

5- Catherine Hughes, Anthony Jackson, and Jenny Kidd, The role of theater in museums andhistoric sites: Visitors, audiences, and learners. International handbook of research in arts education, 2007, pp.679-699.

6. Christine Elizabeth Howard Bailey," From narrative to theatre: living history theatre" (Doctoral dissertation, City University of New York, 1985), p86.

7. Bailey, From narrative to theatre: living history theatre, p88.

8- Hughes, Jackson, and Kidd, The role of theater in museums andhistoric sites, p680. 
9- Hughes, Jackson, and Kidd, The role of theater in museums andhistoric sites, p681.

10. Stephen Alsford and David Parry, Interpretive Theatre A Role in Museums?, Museum Management and Cimtorship (1991), 10, 8-23,p.1.

11- Silvana Barbacci, Science and Theatre: A Multifaceted Relationship Between Pedagogical Purpose and Artistic Expression, 8th International Conference on Public Communication of Science and Technology (PCST), Barcelona, Spain, 3-6 June 2004, p.2.

12- Barbaaci, Science and Theatre,p.2.

13- Dr.wallaa Sadek, Interview, 24August 2017.

14. Dr.wallaa Sadek, Interview, 24August 2017.

15. Dr. Rasha Kamal, Interview by Enas Karim, September25, 2017.

16- Sayeda Safwat, Interview by Enas Karim, September 26, 2017.

17- Hadeer Adel,Interview by Enas Karim, September7, 2017.

18. Tahany Nouh,Interview by Enas Karim, September26, 2017. 